Kohl: a Journal for Body and Gender Research

Vol. 4, No. 1 (Summer 2018)

\title{
Queering Justice: States as Machines of Oppression
}

\author{
Nour Abu-Assab and Nof Nasser-Eddin
}

\begin{abstract}
:
In light of the recent attention to the incarceration, surveillance, and policing of non-normative people in the Middle East and North Africa, this article does not seek to offer alternatives to systems of justice. Instead, our argument revolves around the need to turn the concept of justice on its head, by demonstrating that justice within the context of the nation-state is in its essence a de facto and de jure mechanism of policing and surveillance. To do so, this article draws on Michael Foucault's notion of state-phobia from a de-colonial perspective, intersectional feminist theory, and Hisham Sharabi's conceptualisation of the Arab-state as neo-patriarchal. This article highlights the need to move away from the post-colonial benevolent imaginary of the state, as a result of people's desire for selfdetermination, to a more realistic de-colonial conceptualisation of nation-states that emerged postcolonisation, as sites of oppression. This article will also shed light on the role of civil society in reinforcing the unjust justice sought within nation-state frameworks by drawing on the examples of the recent crackdown on non-normative people in Egypt, and the example of non-normative Palestinians living under occupation. The Egyptian and Palestinian cases are, respectively, one of an allegedly sovereign state that overtly restricts gender and sexual freedom, and another of an occupying state that nominally guarantees gender and sexual rights. These examples are used to demonstrate the theoretical underpinnings of this article, through which we seek to problematise and break binaries of justice versus injustice, and the state versus civil society, in an attempt to queer the concept of justice.
\end{abstract}




\section{Introduction}

We often hear, use, and think of the word justice in response to cases of injustice, inequality, discrimination, oppression, and persecution. In pursuit of justice, we protest, demonstrate, strike, advocate, lobby and resist. Rarely do we question the meaning of justice, but in our minds we know that we pursue fairness. However, are we to be treated fairly through justice mechanisms and frameworks, which claim to do so? In theorising justice, the majority of political theorists referred to justice as guaranteed by the state - in reference to the administration of law, order in society, and access to citizenship. Rawl (1999) was one of the first to describe justice as fairness; however, his theorisation remained limited to justice attained within the structure of the state. Young (1990) pursued a concept of justice as a system of social equality that does not compromise difference, and that eradicates the five faces of oppression: exploitation, marginalisation, powerlessness, cultural imperialism, and violence. Young's definition is, implicitly, grounded in intersectional feminist theory, insofar as she acknowledges that justice cannot be achieved if difference is compromised. Thus, justice as such would become a system that takes difference into consideration in countering the five faces of oppression. Justice systems, within the framework of the nation-state, have been far from acknowledging difference, as their claim to objectivity and value-neutrality, in their application of law and order, imposes uniformity and conformity to the state's legal structures. This leads us to question the possibility of pursuing a queer feminist intersectional justice under state systems that practice all five faces of oppression. A simplistic answer, in the context of injustice in the Middle East and North Africa region, would be democratisation and eradicating dictatorship; then, a reference to international human rights mechanisms would follow - an answer that is boxed within the current world (dis)order, and that emphasises the superiority of a Universalist notion of democracy and human rights. In this article, we critique the notion of justice within the narrow framework of the nation-state, which does not only oversimplify "justice," but moulds it into a tool for oppression.

In relation to gender, sexuality and the policing of bodies and movement, and from a queer perspective, a pursuit of justice, as we want it as queer feminists, is impossible within the framework of the nationstate, which imposes conformity and uniformity. In the context of the Middle East and North Africa, our argument is based on three major pillars: (1) nation-states in the Middle East and North Africa, as products of colonialism, ${ }^{1}$ are fundamentally neo-patriarchal, (2) the nation-state system is de facto reliant on reproduction and the use of female bodies to guarantee national continuation; and consequently (3) the entry point to bodily control is border control and control over freedom of movement. Therefore, a pursuit of queer feminist intersectional justice would undermine, challenge, and question borders and national boundaries. To showcase our argument throughout this article, we briefly refer to case studies from the Middle East and North Africa, including the case of the recent crackdown on non-normative ${ }^{2}$ people in Egypt, and the case of Palestinians living under occupation.

\footnotetext{
${ }^{1}$ We focus, here, on the nation-state system in Arabic-speaking countries as a product of colonisation and are not implying homogeneity. We recognise that states in the region take different forms, including alleged republics, monarchies, quasi-monarchies, etc. We also recognise that, while the nation-state model itself is a product of colonisation, the current manifestations of the model have been adapted to and by local contexts. These adaptations, nevertheless, do not make the model less colonial and/or less patriarchal.

2 We define non-normativity as not abiding by heteronormative and/or patriarchal gender and sexual expectations, including but not limited to self-identified LGBTQ people.
} 
We also shed light on issues of border control and freedom of movement in order to demonstrate that control over bodies, genders, and sexualities are in fact political issues that cannot be dealt with as stand-alone problems. Instead, there is a need to look at the broader global socio-political contexts, and the conditions and structures that created some common patterns of gender, sexual, and bodily oppression $^{3}$ we experience and witness in the Middle East and North Africa nowadays. We do this in an attempt to strip the concept of mere justice - an abstract term that we pursue within queer activism and queer movements, seeking gender and sexual justice and bodily integrity - from its sanctity, locating it instead within the broader socio-political framework of the current "world disorder" 4 (Anderson, 1992). By doing so, we also locate queer struggle as a fight against intersecting forms of oppression that affect us all, as citizens, residents, immigrants, migrants, undocumented, and stateless people located in different colonial locales, united by struggle, and fragmented by borders. ${ }^{5}$

\section{Neopatriarchal Justice}

Behind the appearance of thinking it, most of the writings devoted to the state partake, more or less efficaciously and directly, in the construction of the state, i.e., of its very existence... social science itself has been part and parcel of this work of construction of the representation of the state which makes up part of the reality of the state itself (Bourdieu, 1999:55).

Many social scientists, in agreement with Bourdieu (1999), pushed for a total shift in focus from studying the state as the ultimate representative of social power and authority, to power existing within society outside of the realm of the state, including civil society 6 - a phenomenon referred to by Foucault as "state-phobia" (Dean and Villadsen, 2016). Foucault's conceptualisation of the state as a holder of social power, however, does in no way undermine the agency of other social actors, but this agency takes different forms given the expansion of the state (Nasser-Eddin, 2011). He says in a lecture in 1979:

We might say that what is currently placed in question, from very diverse horizons ... it [sic] is almost always the state, the state in its indefinite growth, the state in its omnipresence, the state and its bureaucratic development, the state with the germs of

\footnotetext{
${ }^{3}$ It is beyond the scope of this paper to detail common patterns of oppression, and differences within local contexts. For some info on this, you may see: Nasser-Eddin, N., Abu-Assab, N. \& Greatrick, A. 2018. "Reconceptualising and contextualising sexual rights in the MENA region: beyond LGBTQI categories." Gender \& Development, 26:1, 173-189.

${ }^{4}$ Anderson, and we agree, argues that the current world order organised through the nation-state system is in fact a "disorder" as in its making it had many repercussions including but not limited to politics of exclusion/inclusion, marginalisation/privileging, etc. which have contributed to a great extent to global inequalities.

5 We use the term "colonial locales" in reference to all state systems, in the Global North and the Global South alike, as we perceive them to be products of colonisation, and by "united by struggle," we refer to the struggle against oppressive state structures broadly.

6 In this article, we use the term civil society in particular to describe organisations and groups, registered and unregistered, working on gender and sexuality issues using mainstream LGBTQ rights frameworks.
} 
fascism that it brings, the state and the intrinsic violence [concealed] under its providential paternalism (translated by Provenzano, 2016).

Despite his critique of the state, Foucault equally criticised the idealisation of civil society as a site of liberty - an analysis we will return to later in this article. Often misunderstood, Foucault's views on the state were re-appropriated to silence critiques of the state system - and have been used to critique what is commonly known and referred to as radical leftist movements. Dhawan (2016), for example, argues that queer state-phobia is dangerous, as it undermines the experiences of subaltern groups, who cannot, but have the desire to, access state functions or state protection. This undermining of the importance of the state and state-phobic queer attitude, she argues, also overshadows stateless persons' desire for a state, or immigrant groups' desire to access state services. From Dhawan's perspective, migrants, undocumented and stateless persons have the desire to access state services, and through the continuous critique of the state system, we are undermining their desire and experiences. We agree that some marginalised groups, who do not have access to state services, indeed desire access to state support. However, we argue that the system itself is the reason behind their exclusion, marginalisation, and the violence they experience in the first place. We, therefore, contest Dhawan's claim that there can be a "benevolent" state in the first place.

The state system initially emerged after the peace treaties of Westphalia in 1648, in order to put an end to the European wars of religion. A quick review 7 of the history of the European nation-state system shows that the European wars of religion emerged due to rivalries and contests over power and authority, and not due to people's desire for self-determination. Most of the sovereign monarchies that came to existence after the peace treaties have in fact been challenged by the masses in a series of revolutions that swamped most of Europe. Over time, however, this system became the modus operandi for the rest of the world, or became the world as most of us know it. Following European revolutions, perceptions of a sovereign nation-state slightly shifted for a brief period of time, and became associated with concepts of liberty, equality, justice, welfare, etc. Thus, our perception of the state, in general, changes depending on the type of rule we experience within it.

Returning to our area of concern, the nation-state in the Middle East and North Africa came as a result of people's desire to overthrow colonisation, which preyed on their human and capital resources. Similar to other colonised contexts, such as in India, liberation from colonisation also meant fictitious borders, which in many cases severed families. However, the "nation state has been a 'compulsory' model at independence of former colonies and dependencies, partly for lack of any other respectable models of statehood" (Zubaida, 2001: 121). Arguably, the state system may be considered the most colonial outcome of the post-colonial world. As many argue (see Aburaiya, 2009; Anderson, 2001 \& 2002; Halliday, 2000; Kumaraswamy, 2003 \& 2006; Massad, 2001), the creation of a sense of nationhood in post-colonial states took place after the creation of the state. Zubaida (2002: 214) gives the example of Iraq, where the creation of a nation that is "territorial, economic, and social reality" followed the creation of a state, which used totalitarianism to guarantee the survival of its sovereignty.

\footnotetext{
${ }^{7}$ For a brief on the role of elites in the European wars of religion, see Nolan, C. J. 2006. The Age of Wars of Religion, 1000-1650: An Encyclopedia of Global Warfare and Civilization, Volume 2. London: Greenwood Publishing Group. 708-710.
} 
In Jordan as well, a sense of Jordanian nationalism was constructed in opposition to Palestinian nationalism in the aftermath of the civil war that took place in Jordan in the early 1970s (Massad, 2001). The Lebanese civil war and the Syrian crisis, have made visible the precarity of the nation-state and the discourse of national unity. The fact that states in the Middle East and North Africa are challenged by processes of modernisation and the rhetoric of authenticity together creates what Sharabi (1988) termed neo-patriarchy in the Arab world at the level of the state. The rhetoric of authenticity, which emerged following the establishment of the nation-state system in the region, has been manifested in local attempts to create "authentic" identities for their own states, often led by those in power within the state. Those in power, who are mostly men, reinforced Sharabi's neopatriarchy within their societies; he states:

Between ruler and ruled, between father and child, there exist only vertical relations: in both settings the paternal will is the absolute will... in social practice ordinary citizens not only are arbitrarily deprived of some of their basic rights but are the virtual prisoners of the state, the objects of its capricious and ever-presenting violence (Sharabi, 1988: 7).

Within this context, the concept of liberty is largely viewed as "antistatal... the more extended the concept of the state, the narrower the scope for freedom" (Ayubi, 2006: 24). This echoes Weber's (1978) definition of the state as "a compulsory political organisation... its administrative staff successfully upholds the claim to monopoly of legitimate use of physical force in the enforcement of its order" (Weber, 1978: 54-5). This enforcement of order, or rule of law as some call it, in fact, is at the heart of contemporary definitions of justice. The crackdown on non-normative people in Egypt, which manifested itself in the imprisonment of around 62 people following the waving of the rainbow flag at a concert in Cairo in September 2017, represents, in many ways, the way the state uses its justice mechanisms to police people's sexualities, practices, and bodies. However, this policing is deeply rooted in the ruling elite's desire to maintain their power by preserving the status quo. In this case, like in many, non-normative people were scapegoated to preserve order. The Egyptian rulers' desire to mobilise the segments of society that sympathise with or support the Muslim-Brotherhood in order to ensure stability in the country was one of the main motives for the crackdown (Parvaz, 2017). By imprisoning non-normative people, the Egyptian state was sending a message to the Islamic-leaning society, making it clear that the state is on their side. This move was an attempt to whitewash their tyranny, military rule, and the economic marginalisation of the majority of Egyptian people, particularly in light of the instability that prevailed in the country in 2017 after the attack on the Coptic church in Cairo and later the mosque in Sinai. In addition to that, the Egyptian authorities charged some of those imprisoned during the 2017 crackdown with belonging to a "cult" or a "group" that threatens the stability of the country, ${ }^{8}$ and it has been treated in some cases as a matter of national security, under article 86 [bis] of Law 58/1937.

${ }^{8}$ CTDC 2017. "Crackdown on Non-Normative People in Egypt: A Policy Brief." Policy Brief No. 5, October 24, 2017. 
In response to the crackdown on non-normative people in Egypt, civil society ${ }^{9}$ condemned the attack and utilised media platforms to pressure the Egyptian authorities to release detainees. Unfortunately, and probably to the detriment of those imprisoned, if anything, the intervention of Global North states is often met with further tightening and control over bodies and sexualities. In this case, the Egyptian state was pushed to intensify its crackdown in order to save face and to ensure that it maintains an image of sovereignty in front of those who oppose it. Interestingly, despite the media attention, parliamentary briefings, and demonstrations, not even one single Global North government issued a statement condemning the crackdown, also due to political reasons and interest in maintaining the status quo in relation to the administration of the country. Under such circumstance, the pursuit of a queer feminist intersectional justice cannot be contained within Universalist narratives of human rights due to the hypocrisy of such allegedly benevolent principles. The pursuit of queer feminist intersectional justice is inevitably state-phobic, and this type of state-phobia is in fact needed to address the root causes of such oppressive mechanisms of so-called justice. In cases as such, the neopatriarchal state's justice mechanisms are in themselves oppressive, while the ruling elites perceive their actions and oppression as just, according to those mechanisms.

However, and returning again to Foucault's conceptualisation, civil society on the local and international levels is not exempt from the contemporary world disorder. The international civil society is in fact controlled by donor governments as well, representing their own elitist agenda, while the local civil society is often trapped between its own state's injustices and the monopolisation of rights' discourses by the international one. In that sense, local civil society 10 in the Global South is faced with antagonistic, competing forces: complicity with oppressive state systems on the one hand, and the narratives and discourses of rights and justice that fit within the cultural imperialist narratives of the Global North on the other, which also operates within neopatriarchal state structures. In addition to this neopatriarchy, narratives of nationalism within the nation-state in the Middle East and North Africa are also oppressive insofar as they are constructed to serve the continuation of the nation through reproduction and bodily control.

\section{Reproducing Collectivities}

Understanding the nature of marriage is essential for understanding any kinship system... kinship and marriage organise productive and reproductive relationships... the organisation of marriage and of the relationships built around it should provide explanations to the organisation of gender relationships (Shahd, 2004: 13).

"Torn" between "imperatives" of patriarchy and modernisation (Moghadam, 1995: 12), the model of the nation-state in the Middle East and North Africa ensures that it maintains control over bodies, and especially female bodies, to guarantee the continuation of the nation. As we have established so far, the nation-state in the Middle East and North Africa is neopatriarchal in the sense that it replicates the

\footnotetext{
9 Here, we are referring mostly to organisations and groups, registered and unregistered, working specifically using LGBTQ rights framework to advocate for gender and sexual rights.

$10 \mathrm{lbid}$.
} 
same structures existing within the patriarchal family unit. Within this unit, the family as the first site of women's oppression, and women as wives, mothers, and sisters, are held responsible for the reproduction of ethnic and national identities (Charles and Hintjens, 1998). In her study of Tunisia, Morocco, and Algeria, Charrad (2003) highlights the central role state legislation plays in shaping gender relations within the family; she emphasises that the legal frameworks place the family at the centre of women's lives. ${ }^{11}$ This narrative around women's roles within the nation-state has implications that include but are not limited to imposing control over women's sexuality and ensuring the continuation of the heteronormative family structure. As Fortier (2000: 168) puts it, "ideas of authenticity are defined in terms of fixed gender roles and heterosexual norms... the prioritisation of irreducible gender differences - that also signal irreducible heterosexual complementarity - acts as a display of cultural continuity." Therefore, controlling and policing bodies and sexuality and regulating relationships serve to benefit the neopatriarchal state on the one hand, and to maintain its status quo on the other.

In addition to the political nature of the policing of bodies that took place in Egypt, the preservation of the family unit also serves the neopatriarchal states' agendas. Maintaining the patriarchal family unit as the main building block of society, and imposing control over bodies are necessary to preserve an allegedly "authentic" cultural national identity, as the state is seen as an extension of the patriarchal family unit (Sharabi, 1988). Kings or rulers are portrayed as the "fathers" of the communities they rule and as heads of societies, and the nations are portrayed as their families. Like in patriarchal families, the king or president has absolute power over his community, and the nation should respect, fear, and follow the ruler. The metaphorical use of the patriarchal family to describe rulers' relation to citizens reinforces the paradigm of the patriarchal family, and, vice versa, the preservation of the patriarchal family reinforces the power of the rulers. As Sharabi, again, puts it:

The nation as family, a metaphor very dear to Arab rulers revolutionary, conservative, and semi-tribal alike - is the trans-ideological model of authority common to all neopatriarchal regimes, regardless of ideology or socioeconomic system... the same authoritarian vertical relations existed everywhere, preventing genuine social integration and keeping the majority of the population outside the mainstream of social and political life (Sharabi, 1988: 132-3).

In order to preserve the already fragile imaginary of the nation, states across the world, in varying degrees, regulate intimate sexual relationships by legitimising some through their institutions and apparatuses. Through marriage, states do not only keep track of reproduction, but also create a system of surveillance and policing of sexualities and intimate relationships. Marriage becomes the most legitimate relationship, while alternative forms of relating including polyamorous, open, and group relationships are not considered as legitimate. Therefore, queer feminist intersection justice, a justice that acknowledges and recognises difference when addressing faces of oppression, cannot be attained through access to the state system, or to marriage equality, as state surveillance and policing of

\footnotetext{
11 It is important to note here that this is not a phenomenon that is exclusively omnipresent in the MENA region. Right-leaning governments in the Global North, including the Trump Administration in the USA, and the conservative government in the UK, often do emphasise the importance of the family, family values and the good society.
} 
relationships are another form of oppression. Thus, pro-marriage equality mainstream liberal12 LGBTQ rights narratives are by no means a step forward to attain justice, as we want it.

The Zionist settler colony is the ultimate example of adopting such liberal LGBTQ rights discourses. "Israel" disguises the atrocities it commits against the Palestinians through promoting itself as adoptive of gay rights and a saviour of the Palestinians fleeing family persecution, and promoting its capital as the gay capital of the world. By doing so, it presents itself as modern and progressive vis-à-vis its other "barbaric," "homophobic," Palestinian "Arab" other - a phenomenon termed as pinkwashing ${ }^{13}$ (AbuAssab, 2014a). In fact, the settler colony "Israel" is far from a saviour, and far from being a guarantor of LGBTQ rights. In the colony, lesbians and gays are only tolerated if they lead heteronormative lifestyles, while transgender people are very much discriminated against and face hate crimes (AbuAssab 2014b). Reproduction, however, is favoured. Lesbian couples are encouraged to have babies, and IVF is provided by the state free of charge for lesbians to increase the number of Jewish people in occupied Palestine and to outnumber the Palestinians. Colonial gay men are encouraged to find surrogate mothers for their sperms in South Asian countries at discounted prices. Thus, tolerance within the context of the colony is meant to guarantee the continuation of the nation. In addition to reproduction, in the Zionist colonialist imaginary, and even within intimate settings, the other Palestinian "Arab" is always subordinated through power hierarchies. During an encounter ${ }^{14}$ with a self-identified "Israeli" lesbian, whose partner was Palestinian, she said: "my nationalist Israeli acquaintances' reaction to our relationship was disgusting. They started saying things to me like, so do you give it to her the way we give it to them?" referring to non-consensual violent sexual practices, sexual subordination and sexual power hierarchies.

The impact of the reproduction of the nation is not only limited to the Zionist state, but also extends to a means of resistance among Palestinians, further amplifying control over bodies and sexualities in the name of securing a nation-state. During a piece of qualitative research we embarked ${ }^{15}$ to look at Palestinians' perceptions of homosexuality, we found that the way the Zionist entity constructs the "other" pushes Palestinians to define the boundaries of their group, and increases anti-homosexual sentiments among the Palestinian community. During interviews with Palestinians, we were told: "Israel wants to promote homosexuality among Palestinians to decrease the number of Palestinians and outnumber us to be able to take more land." 16 During a similar conversation, we were also told: "this is what Israel wants us to become, a broken nation, whereby people stop procreating and we end up ethnically cleansed." This type of anti-homosexual sentiments is justified through a claim to resisting the

\footnotetext{
12 Most mainstream LGBTQ rights narratives are also being constructed by neoliberal elites, across the world, as the current world disorder has created a global class characterised by affluence, access to similar cultural capital, including but not limited to lifestyle and fashion, and complicity with global structures of inequality, which are beyond the scope of this paper to address.

${ }^{13}$ Pinkwashing refers to the use of LGBTQ rights discourses by the Zionist occupation in order to promote itself as progressive, modern, a protector of LGBTQ rights, and even a protector of LGBTQ Palestinians, for the purpose of harnessing international support, justifying its colonial conquests in Palestinian lands, and whitewashing the atrocities it commits against the Palestinians.

14 The encounter was involving one of the authors during an international academic conference. Explicit consent to use this experience for research has been granted.

${ }_{15}^{15}$ Research findings were presented at a conference (Abu-Assab, 2014b).

16 lbid.
} 
occupation and the ethnic cleansing of the Palestinians, which gives it legitimacy and makes it harder to counter as it is framed as reactionary to the Zionist agenda. Pinkwashing done by the Zionist state perpetuates a vicious circle of negative sentiments towards non-normative genders and sexualities that is difficult to counter by non-normative Palestinians in light of the occupation, as they become perceived as "westernised," "traitors," and, above all, "anti-nationalist."

In addition to that, trapped between the hammer and the anvil, Palestinian civil society in general, and particularly those promoting gender and sexual rights in addition to self-proclaimed feminist organisations, becomes an additional site of oppression and silencing for non-normative people. Immersed in the fight against pinkwashing, and in promoting women's rights, Palestinian civil society does not only ignore the atrocities committed by the Palestinian authorities in the West Bank, but also prevents people from talking about them so that such stories do not reinforce the image of the "homophobic" and "sexist" Palestinian. Speaking out against the Palestinian Authority or against sociocultural oppression becomes a taboo sacrificed for the sake of protecting the nation and its image, and some feminist organisations completely silence and refuse to engage in issues related to nonnormative genders and sexualities, claiming that it is not a priority within national discourses. Hence, civil society employs the master's tools against its own people and communities, contributing to an injustice for the sake of a perceived national justice. This supports Foucault's critique of the idealisation of civil society: in light of the lack of a sovereign Palestinian state, Palestinian civil society resisting the occupation constitutes another site of political power and control, albeit limited. In its complicity in "preserving the image of the nation," civil society under occupation restricts its field of vision to the boundaries of the nation, failing to identify possibilities beyond state boundaries and borders. Within the context of Palestine, gender and sexual justice is neither pursued inwardly nor outwardly. Hence, an unpacking of national identity sometimes "demands a 'reading of the silences'... understanding the unspoken is a crucial aspect of any investigation, capturing the silence" (Handrahan, 2002: 39). Reading silences against the fight for the eradication of borders, then, is necessary to attain queer feminist intersectional justice.

\section{Conclusions: Border Control versus Body Control}

For even people remaining in familiar and ancestral places find the nature of their relation to place ineluctably changed, and the illusion of a natural and essential connection between the place and the culture broken (Gupta and Ferguson, 1992: 10).

Nations are imagined, and so are nation-states with their borders. States, and consequently their nations, particularly in the Middle East and North Africa, have become, in all their forms, machines of oppression. These machines of oppression do not only police, surveil, and incarcerate, but also constitute virtual prisons for their citizens, particularly for their non-normative inhabitants. Our relationship to the state in the region is one that is neither natural nor innate; instead, it is fluid and changing. For the many of us living under dictatorship, our relationship to the state system is not positive, not only due to queerness or non-normativity, but also because states have been sites of oppression for a long time. We have demonstrated so far that much of gender and sexual oppression is 
done in the name of peoples' right to self-determination, right to a nation-state, and right to access justice through state mechanisms. When we speak of justice within the framework of a state, we are fundamentally speaking of justice through and within machines of oppression, and justice based on injustice is of no account.

We try to manoeuvre, negotiate, and tiptoe around a world order that is fundamentally disorderly. Our bodies move within state borders that seem to protect the borders of the Global North, and movement outside of these borders is often conditioned by the availability of capital. The state in all its forms, with artificial borders, is a site of restriction, policing, and oppression. It confines, incarcerates, and punishes the human within its borders - a big prison cell. These borders do not only control and police our bodies, but also restrict our imagination, through creating unnatural bonds to an imagined nation, imagined homeland, and imagined collective memories. We think within a box - a manmade ${ }^{17}$ box that encapsulates and limits our resistance. It is the same box that defeats our queerness, which is meant to disturb identities rather than define them. The intention of this article is not to offer alternatives, but to rather open up queer possibilities that could exist if, in our pursuit of queer feminist intersectional justice, we think and act outside the box, the borders, and the boundaries of the oppressive nation-state. Thus, a queer intersectional feminist justice is one that acknowledges difference, embraces non-conformity and non-normativity, and recognises that due to the intersectionality of our experiences, there is not one singular system of law, governance, and rights that can act as like a panacea to eradicate all faces of oppression. A queer intersectional feminist justice is one that pushes for diverse forms of justice, addressing the root causes of social injustice rather than punishing the individual for "wrongdoing." It prompts an inquiry into the why and how injustice repeatedly occurs, and addresses the structural problems leading to oppression, focusing on remedying the cause rather than addressing its symptoms. Therefore, we aim to queer justice, as we know it, in order to become able to collectively articulate it, as we want it.

17 The use of the word manmade is intentional. 
Kohl 4.1

\section{References}

Abu Assab, N. 2014a. "Affected and Saviours: Power, Agency and LGBTQ Struggle in Conflict Areas." Emergencies and Affected People Conference: Philosophy, Policy and Practice. The University of Birmingham.

Abu Assab, N. 2014b. "Decolonising' Queer Migration." Queer Migration and Mobilities Workshop. The Department of Sociology, Lund University, Sweden.

Aburaiya, I. 2009. "Islamism, Nationalism, And Western Modernity: The Case Of Iran And Palestine." International Journal Of Politics, Culture And Society, 22, 57-68.

Anderson, B. 1992. "The new world disorder." New Left Review, 193, 3-13.

Anderson, B. 2001. "Writing the Nation: Textbooks of the Hashemite Kingdom of Jordan." Comparative Studies of South Asia, Africa and the Middle East, xxi, 5-14.

Anderson, B. 2002. "The Duality of National Identity in the Middle East: A Critical Review." Critical Middle Eastern Studies, 11, 229-250.

Ayubi, N. N. 2006. Over-Stating The Arab State: Politics And Society In The Middle East. London: I.B. Tauris.

Bourdieu, P. 1999. "Rethinking The State: Genesis And Structure Of The Bureaucratic Field." In: Steinmetz, G. (Ed.) State/Culture: State-Formation After The Cultural Turn. Cornell: Cornell University Press.

Charles, N. \& Hintjens, H. (Eds.) 1998. Gender, Ethnicity And Political Ideologies. London: Routledge.

Charrad, M. 2003. "State And Gender In The Maghrib." In: Sabbagh, S. (Ed.) Arab Women: Between Defiance And Restraint. Massachusetts: Olive Branch Press.

CTDC 2017. "Crackdown on Non-Normative People in Egypt: A Policy Brief." Policy Brief No. 5, October 24, 2017.

Dean, M. \& Villadsen, K. 2016. State of Phobia and Civil Society: The Political Legacy of Michel Foucault. Standford: Stanford University Press.

Dhawan, N. 2016. "Homonationalism and State-phobia: The Postcolonial Predicament of Queering Modernities." In: María Amelia Viteri and Manuela Lavinas Picq (Eds.) Queering Paradigms V: Queering Narratives of Modernity. Oxford: Peter Lang. 51-68.

Fortier, A. M. 2000. Migrant Belongings: Memory, Space, Identity. Oxford: Berg.

Gupta, A. \& Ferguson, J. 1992. "Beyond 'Culture': Space, Identity, And The Politics Of Difference." Cultural Anthropology, 7, 6-23.

Halliday, F. 2000. Nation, and Religion in the Middle East. London: Saqi Books.

Handrahan, L. 2002. Gendering Ethnicity: Implications For Democracy Assistance. London: Routledge.

Kumaraswamy, P. R. 2003. "Problems of Studying Minorities in the Middle East." Alternatives: Turkish Journal of International Relations, 2, 244-264.

Kumaraswamy, P. R. 2006. "Who Am I? The Identity Crisis in the Middle East." Middle East Review of International Affairs, 10, 63-73.

Massad, J. A. 2001. Colonial Effects: The Making Of National Identity In Jordan. New York: Columbia University Press.

Moghadam, V. M. 1995. "The Political Economy Of Female Employment In The Arab Region." In: Khoury, N. F. \& Moghadam, V. M. (Eds.) Gender And Development In The Arab World: Women's Economic Participation: Patterns And Policies. New York: Zed Books. 
Nasser-Eddin, N. 2011. The Intersectionality of Class and Gender: Women's Economic Activities in East and West Amman. Unpublished thesis.

Nasser-Eddin, N., Abu-Assab, N. \& Greatrick, A. 2018. "Reconceptualising and contextualising sexual rights in the MENA region: beyond LGBTQI categories." Gender \& Development, 26:1, 173189.

Nolan, C. J. 2006. The Age of Wars of Religion, 1000-1650: An Encyclopedia of Global Warfare and Civilization, Volume 2. London: Greenwood Publishing Group. 708-710.

Parvaz, D. 2017. "U.S. silent as Egypt considers new law outlawing homosexuality - and it's worse than you think." Think Progress. Available at: https://goo.gl/CCP5w6. November 10, 2017. [Accessed: May 20, 2018].

Provenzano, L. 2016. "Foucault on the Aporias of State-Phobia: Michel Foucault's Collège De France Lectures." [Blog]. Available at: http://bit.ly/2FnTFev. [Accessed March 1, 2018].

Rawl, J. A. 1999. Theory of Justice: Revised Edition. Oxford: Oxford University Press.

Shahd, L. S. 2004. An Investigation of the Phenomenon of Polygamy in Rural Egypt. Cairo: The American University In Cairo Press.

Sharabi, H. 1988. Neopatriarchy: A Theory of Distorted Change in Arab Society. Oxford: Oxford University Press.

Weber, M. 1978. Economy and Society: An Outline of Interpretive Sociology. Berkeley: University Of California Press.

Young, I. M. 1990. Justice and the Politics of Difference. Princeton: Princeton University Press.

Zubaida, S. 2001. Islam, the People and the State: Political Ideas and Movements in the Middle East. London: I.B. Tauris.

Zubaida, S. 2002. "The Fragments Imagine The Nation: The Case Of Iraq." International Journal of Middle East Studies, 34, 205-215. 